\title{
Relationship between Knowledge, Clothing Cleanliness, Towel Cleanliness and Environmental Sanitation with Scabies Incidents at the Pekanbaru City Child Special Development Institute (LPKA) in 2019
}

\author{
Ruth Novyna Carolyne $\mathbf{T}^{\mathbf{1}}$, Namora Lumongga Lubis ${ }^{2}$, Nurmaini ${ }^{\mathbf{3}}$ \\ ${ }^{1,2,3}$ Public Health Sciences, Universitas Sumatra Utara, Indonesia \\ carolyneruthnovina@yahoo.co.id
}

\begin{abstract}
Scabies is a skin disease related to the environment and human behavior. In Indonesia, scabies is still a public health problem. Scabies is found in places with unsanitary environments and poor personal hygiene such as dormitories, Islamic boarding schools and prisons. In LPKA Pekanbaru City, there were $38.33 \%$ cases of scabies. This case increased from the previous year, where cases in 2017 were $34 \%$. This study aims to analyze the factors that influence the incidence of scabies in the Class II Class II Special Development Institution for Children in Pekanbaru City in 2019. The research design used was cross sectional with a sample size of 120 children obtained using the total population. The instrument used in this study was a questionnaire. The data obtained in this study were analyzed by univariate, bivariate and multivariate using multiple logistic regression tests. The results showed that there was a relationship between cleanliness of clothes $(p=0.003)$, cleanliness of towels $(p=0.014)$, and environmental sanitation $(p=0.042)$ with the incidence of scabies. Meanwhile, the knowledge variable $(p=$ 0.533 ) was not related to the incidence of scabies. In this study, if students have poor hygiene clothes, towels, and sanitation, they have the opportunity to experience scabies at the Pekanbaru City Children's Special Development Institute.
\end{abstract}

Keywords

knowledge, hygiene;

sanitation; scabies

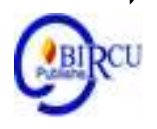

\section{Introduction}

Efforts to Increase Health Degrees in Indonesia until now have not been considered to have an Continuation of Health Development Continuation, this is when compared to neighboring Countries Health Degrees in Indonesia are still considered low. One indicator of the success of development for the development of an ideal nation is the establishment and organization of a good health system, in this discussion covering physical and psychological aspects which are added with spiritual conditions, personality and empowerment. This aspect discusses the discussion space on health development which is interrelated with other aspects. (Shinta et al, 2020)

Skin disease is a disease related to the environment and human behavior. In Indonesia, skin disease is still a public health problem. The causes of skin diseases also vary widely, ranging from viruses, germs, fungi and parasites. Skin diseases caused by viruses can be in the form of herpes, skin diseases caused by germs can be in the form of carbuncles and furuncles or boils, caused by fungi in the form of candidiosis and caused by parasites can be in the form of pediculosis and scabies. 
Skin diseases that occur in Indonesia also vary, but what most people in Indonesia often experience is scabies skin disease. Scabies skin disease is a contagious skin disease that will cause symptoms of itching, especially at night, and is a very easily transmitted disease. Scabies skin disease caused by Sarcoptes scabiei hormoneis. Scabies disease occurs a lot in Indonesia because Indonesia has a tropical climate, and in tropical regions, the development of parasites is very easy, thus increasing the risk of scabies (Soedarto, 2003).

Scabies is spread by the sufferer's direct contact with those around him. Scabies also spreads in humid, unsanitary conditions, with excess housing capacity such as orphanages, dormitories and prisons. It is feared at these dwellings that the spread of scabies will be transmitted very quickly due to conditions that force them to live side by side, especially for those who live in prisons with over capacity conditions. Apart from those who live in prisons, scabies can also be transmitted to families who visit these prisons. This causes families who visit to become prions (carriers) of scabies for people outside prison.

Scabies does not cause death, but it is very disruptive to daily activities and can infect other people. The most frequent complication of scabies is secondary bacterial infection due to scratching. As a result of itching, a person will continue to scratch and cause injury, the wound can enter bacteria that can cause infection. In more severe complications scabies can cause crusts and scales all over the body surface. In this phase, scabies is very difficult to cure and very contagious.

World Health Organization (WHO) in 2014, the incidence of scabies reached 130 million sufferers worldwide. In addition, based on data from the International Alliance for the Control Od Scabies (IACS) in 2014, the incidence of scabies varies widely from 0.3 percent to 46 percent. In Indonesia alone, the prevalence of skin diseases is growing. This is evidenced by Indonesia's health profile in 2015 which shows that skin and subcutaneous tissue diseases are in the third rank of the top ten diseases in outpatients in all hospitals in Indonesia based on the number of visits, namely 192,414 visits, new case visits as many as 122,076 visits and old case visits were 70,338 visits.

Based on data recorded at the Riau Provincial Health Office in 2016, the incidence of scabies reached 13,046. In Pekanbaru city itself, the incidence of scabies reached 1,257 cases and was the fourth highest after Indragiri Hilir Regency with 3246 cases, Kampar Regency with 1779 cases, and Bengkalis Regency with 1514 cases of scabies.

Many cases this will also have a negative impact on the country's economy because they have to spend a budget for the treatment and recovery of this disease. The incidence of this skin disease is usually found in places with conditions that are less sanitary, the occupancy is too narrow and crowded, and the cleanliness is not maintained such as dormitories, Islamic boarding schools, and prisons.

Community Institutions or called Lapas are places to provide guidance to prisoners who violate the law in Indonesia. Before being known as prison in Indonesia, it was first known as prison. The condition of prisons in Indonesia, which are all stated to be overcapacity, makes this place a dense and unsanitary residence. Prisons residents live in a narrow room with several people who make even sleepers have to squeeze together and open the way to transmit illnesses.

Child prisons or also known as Institutions for Special Guidance for Children (LPKA) are institutions for guiding children aged 12-18 years who violate the law because they should not be combined with adult prisons to reduce the risk of violence against children in prisons. In the Class II Special Development Institution for Children (LPKA) in Pekanbaru City, it was found that scabies was in the first rank with the highest number of cases that occurred from year to year. The number of cases of scabies skin disease in the Children's Prison or Special Guidance Institution for Children in Pekanbaru City was found from the total number of 
students as many as 120 children, 58 children with scabies skin disease (48.3\%). Almost all skin infections are transmitted through direct or indirect contact to the skin. The factors that play a role in the transmission of scabies skin disease are low knowledge of scabies, bad attitudes, low socioeconomic conditions, poor personal hygiene, behavior that does not support health, and an unsanitary environment.

Based on the results of an initial survey conducted at the Class II Special Development Institute for Children in Pekanbaru City, the number of residents of students as of August 2019 was 120 children. LPKA's environmental conditions are arguably less sanitary. Starting from the inadequate supply of clean water, the number of residential cells / rooms that are not comparable to those of correctional students, resulting in over capacity and dirty living rooms due to the lack of attention of correctional students in terms of cleanliness and humid living room environment due to lack of ventilation who qualify.

The developments and changes that continue to occur over time also lead to changes in every social structure that exists in society. There are those who are getting stronger, there are those that are weakening, fading even slowly forgotten by the people. This is what happens in the existence of social institutions in the midst of society. In fact, this social institution is an important part of the realization of a controlled and controlled community life in accordance with the norms that have developed in each region. (Husda and Zubaida, 2018) From the results of interviews with nurses at the LPKA clinic, the most common disease suffered by correctional students is scabies and has always been the most common disease throughout the year.

\section{Research Methods}

This research is a type of quantitative research in the form of observational analytic which explains a situation or situation of phenomena that can occur and then analyzed using a crosssectional approach. The cross-sectional approach is a study to study the dynamics of the correlation between risk factors and effects, by means of approaching, observing, or collecting data at once (point time approach) (Notoatmodjo, 2012). The number of samples of 120 children obtained using the total population. The instrument used in this study was a questionnaire. The analysis used multiple logistic regression test (multiple regression).

\section{Results and Discussion}

Data analysis was conducted to analyze the relationship between the independent variables (knowledge, cleanliness of clothes, clean towels, and environmental sanitation) with the dependent variable (incidence of scabies).

Table 1.Respondent Characteristics Frequency Distribution

\begin{tabular}{ccc}
\hline $\begin{array}{c}\text { Respondent } \\
\text { Characteristics }\end{array}$ & $\mathrm{n}=120$ & $\%$ \\
\hline Age & & \\
\hline <17 Years & 45 & 37.5 \\
$\geq 17$ years & 75 & 62.5 \\
\hline Total & 120 & 100.0 \\
\hline Long Stay & & \\
\hline$<1$ year & 95 & 79.2 \\
$\geq 1$ year & 25 & 20.8 \\
\hline Total & 120 & 100.0 \\
\hline
\end{tabular}


Based on table 1, it can be seen that the age variable shows that the respondents who are above or equal to 17 years, namely students with ages ranging from 17 years to 20 years are 75 people $(62.5 \%)$. In the long stay variable, it is known that There were 95 respondents $(79.2 \%)$ who lived in the Special Guidance Institution for Children (79.2\%) with an average of students who were in the category of less than one year, namely students with a length of stay ranging from three months to nine months.

Table 2. Characteristics Based on Knowledge Variables, Clothes Cleanliness, Towel Cleanliness, Environmental Sanitation and Scabies Incidence

\begin{tabular}{lll}
\hline $\begin{array}{l}\text { Respondent } \\
\text { Characteristics }\end{array}$ & $\mathrm{n}=120$ & $\%$ \\
\hline Knowledge & & \\
$\quad$ Good & 12 & 10.0 \\
$\quad$ Not good & 108 & 90.0 \\
$\begin{array}{l}\text { Clothes Hygiene } \\
\quad \text { Good }\end{array}$ & 42 & 35.0 \\
$\quad$ Not good & 78 & 65.0 \\
$\quad \begin{array}{l}\text { Towel Cleanliness } \\
\quad \text { Good }\end{array}$ & 80 & 66.7 \\
$\quad$ Not good & 40 & 33.3 \\
Sanitation & & \\
$\quad$ Good & 26 & 21.7 \\
$\quad$ Not good & 94 & 78.3 \\
The Scabies Incident & & \\
$\quad$ Yes & 46 & 38.3 \\
$\quad$ Not & 74 & 61.7 \\
\hline
\end{tabular}

In the knowledge variable it is known that respondents who had good knowledge were as many as 12 people (10.0\%) and had poor knowledge as many as 108 people $(90.0 \%)$. In the clothing hygiene variable, it is known that respondents who have clean clothes in the good category are 42 people $(35.0 \%)$ and 78 people $(65.0 \%)$ are in poor categories.

In the towel hygiene variable, 80 people $(66.7 \%)$ were in the good category and 40 people $(33.3 \%)$ were in the poor category. In the sanitation variable, it is known that 26 people $(21.7 \%)$ have good sanitation and as many as 94 people $(78.3 \%)$ have poor sanitation. Respondents who experienced the incidence of scabies were 46 people (38.3\%).

Table 3. The Relationship between Characteristics, Knowledge, Clothes Hygiene, Towel Cleanliness, and Sanitation with Scabies Incidence

\begin{tabular}{|c|c|c|c|c|c|c|c|}
\hline \multirow{3}{*}{ Variable } & \multicolumn{6}{|c|}{ The Scabies Incident } & \multirow{3}{*}{ p. value } \\
\hline & \multicolumn{2}{|c|}{ Yes } & \multicolumn{2}{|c|}{ Not } & \multicolumn{2}{|c|}{ Total } & \\
\hline & $\mathrm{N}$ & $\%$ & $\mathrm{~N}$ & $\%$ & $\mathrm{~N}$ & $\%$ & \\
\hline \multicolumn{8}{|l|}{ Age } \\
\hline$<17$ Years & 12 & 26.7 & 33 & 73.3 & 45 & 100.0 & 0.065 \\
\hline$\geq 17$ years & 34 & 45.3 & 41 & 54.7 & 75 & 100.0 & \\
\hline \multicolumn{8}{|l|}{ Long Stay } \\
\hline$<1$ year & 38 & 40.0 & 57 & 60.0 & 95 & 100.0 & \multirow{2}{*}{0.616} \\
\hline $\begin{array}{l}\geq 1 \text { year } \\
\text { Knowledge }\end{array}$ & 8 & 32.0 & 17 & 68.0 & 25 & 100.0 & \\
\hline Good & 6 & 50.0 & 6 & 50.0 & 12 & 100.0 & \multirow{2}{*}{0.533} \\
\hline Not good & 40 & 37.0 & 68 & 63.0 & 108 & 100.0 & \\
\hline
\end{tabular}




\begin{tabular}{lccccccc}
$\begin{array}{l}\text { Cleanliness } \\
\text { Clothes }\end{array}$ & & & & & & & \\
Good & 8 & 19.0 & 34 & 81.0 & 42 & 100.0 & 0.003 \\
$\begin{array}{l}\text { Not good } \\
\text { Cleanliness }\end{array}$ & 38 & 48.7 & 40 & 51.3 & 78 & 100.0 & \\
Towel & & & & & & & \\
Good & 24 & 30.0 & 56 & 70.0 & 80 & 100.0 & 0.014 \\
Not good & 22 & 55.0 & 18 & 45.0 & 40 & 100.0 & \\
Sanitation & & & & & & & \\
Good & 5 & 19.2 & 21 & 80.8 & 26 & 100.0 & 0.042 \\
Not good & 41 & 43.6 & 53 & 56.4 & 94 & 100.0 & \\
\hline
\end{tabular}

Based on table 3, it is known that the results of the analysis of the relationship between age and the incidence of scabies using the chi-square test obtained the value of $p=0.065$ ( $p$ > 0.05) so it can be seen that there is no relationship between age and the incidence of scabies in the Class II Special Development Institute for Children in Pekanbaru City. Based on the results of the research on the age variable, it is known that there are 45 students aged less than 17 years (37.5\%) and 75 children aged over or equal to 17 years $(62.5 \%)$. In the research results, it can be seen that the dominant children over 17 years of age.

In the age variable, according to the results of the study, it was found that children over 17 years of age had more scabies with than children with the age range under 17 years. This is also in accordance with the results of observations, where children aged 17 to 20 years have a habit of being lazy compared to children aged 14 to 16 years. At the time of the study, students under 17 years of age were seen to be more active in cleaning the residential room and there was a factor from the older the child's age meant that the greater his power in the residential room resulted in children over 17 years of age more often ordering their younger siblings in prisons to cleaning the dwelling room while those who are older will be lazy to clean because they feel they are able to order their other siblings.

The results of this study are in line with research by Ariningtyas (2019) which states that there is no relationship between age variables and the incidence of scabies. [8] According to Pawening (2019), poor individual hygiene can increase infection of the sarcoptes scabiei mite, but humans infected with these mites do not pay attention to variables of age, sex or race as well as economic and social status.

The results of this study are not in line with Noor's (2008) study which found that there is a relationship between age and the amount of risk for certain diseases and the nature of resistance in various certain age groups. [10] According to Notoatmojo (2007), age can affect a person's perceptive power and mindset, where the older a person gets, the more his ability and mindset will develop, so that the person's knowledge will be better.

The results of the analysis between the length of stay and the incidence of scabies using the chi-square test obtained the value of $p=0.616$ ( $p>0.05)$ so that it can be seen that there is no relationship between length of stay and the incidence of scabies at the Class II Special Development Institute for Children in Pekanbaru City. Based on the results of the study on the length of stay variable, it was known that there were 95 students who lived for less than 1 year $(79.2 \%)$ and 25 students who lived for more than 1 year $(20.8 \%)$.

In the research results, the most dominant is students who live for less than one year in the Special Development Institution for Children. This is because the sentence period given is not too long as stated in Law No. 11 of 2012 article 3 concerning the Criminal Justice System that children are sentenced to prison only as a final process and not for a long period of time. 
In this study, most of the students who suffered from scabies were students who lived less than 1 year in special child development institutions. This is because new students have not been able to adapt to the prison environment. New students do not know about the health problems that occur at LPKA so they follow bad hygiene patterns such as lazy because when they are there they do not have many activities and mostly just sleep if there are no coaching activities from LPKA, besides that it is also a habit. Students who are lazy to take a bath because there are no activities that make them just sleep but don't change their clothes.

The results of this study are in line with research by Ariningtyas (2019) which revealed that the length of stay was not significant so there was no relationship between length of stay and the incidence of scabies. Unlike the research conducted by Azizah (2013) it is not in line with the results of this study. The results of his study stated that length of stay has a relationship with the incidence of scabies. Children who experience the most scabies are new children and have not been able to adapt to the environment so that new children do not know about the life of the pesantren, including health problems in the pesantren.

The results of the analysis of the relationship between knowledge and the incidence of scabies using the fisher's exact test obtained a value of $p=0.533(p>0.05)$ so that it can be seen that there is no relationship between knowledge and the incidence of scabies at the Class II Special Development Institute for Children in Pekanbaru City. Based on the results of research on the knowledge variable, it was known that 12 students $(10 \%)$ had good knowledge and 108 students $(90.0 \%)$ had poor knowledge.

Students who have good knowledge or poor knowledge may suffer from scabies, because the incidence of scabies can be caused by variables other than knowledge. In this study, it is known that the correctional students' knowledge is still lacking. This is due to the background of the students, who almost all dropped out of school, starting from elementary school and some who did not go to school since they were small and a small proportion of them also dropped out of school in the first grade of junior high school. From this background, students do not understand about scabies, what causes it and from the research results, almost all students have never heard about scabies skin disease.

Students at special guidance institutions for children who suffer from itching think that their disease is just normal itching and they even give the disease its own name, namely kurnak (delicious dredge). The name of this kurnak was made by them because itching on

their body when scratched it will feel better, even though in fact scabies when scratched will cause wound complications and end up in severe infection and there are victims who have experienced this at a special guidance institution for children.

The results of this study are in line with Ridwan's research (2017) which states that there is no relationship between knowledge and the incidence of scabies. [13] However, the results of this study are different from Rohmawati's (2010) study, where the knowledge variable studied showed that there was a relationship between knowledge and the incidence of scabies and knowledge greatly influenced the occurrence of scabies.

The results of the analysis of the relationship between the cleanliness of clothes and the incidence of scabies using the chi-square test obtained the value of $p=0.003(p<0.05)$ so that it can be seen that there is a relationship between the cleanliness of clothes and the incidence of scabies in the Class II Special Development Institute for Children in Pekanbaru City. Based on the results of the research on the clothing hygiene variable, it was known that there were 42 students $(35.0 \%)$ who had good clothing hygiene while 78 students $(65.0 \%)$ had poor clothing hygiene.

The results of this study are in line with research by Julia (2013) which states that there is a significant relationship between changing clothes and the incidence of scabies. According to Irianto in Farihah (2016), from the aspect of changing clothes, the way that can be done to 
maintain personal hygiene is by changing clothes that have just been used after bathing with clean clothes that have been washed with detergent or soap, dried in the sun and have been ironed. . Maintaining the cleanliness of clothes is one form of effort to prevent germs from multiplying, as well as giving a sense of comfort to oneself, and preventing skin diseases from being attacked. Maintaining proper clothing hygiene can reduce the risk of students getting scabies. This is in accordance with the theory that clothing plays a role in the transmission of scabies mites through indirect contact, thereby affecting the incidence of scabies.

The results of this study are in accordance with the habits of students who mostly pay less attention to the cleanliness of clothes. This can be seen from the habits of students who rarely change clothes, like to use clothes that are still damp, and the habit of changing clothes frequently with roommates. In addition, observations in the residential room show that clothes that have been worn are not immediately washed but are hung above the bathroom door and on the wall or on the window and most of the clothes are joined and stuck together and piled together, thus increasing the risk of scabies transmission. .

The results of the analysis of the relationship between towel cleanliness and the incidence of scabies using the chi-square test obtained $p$ value $=0.014(p<0.05)$ so that it can be seen that there is a relationship between towel cleanliness and the incidence of scabies at the Class II Special Development Institute for Children in Pekanbaru City. Based on the results of the research on the towel cleanliness variable, it was known that 80 students $(66.7 \%)$ had good towel hygiene while 40 students $(33.3 \%)$ had poor towel hygiene.

From the results of observations in the field, it was seen that there were still students who often hung towels in the room when it was damp and did not expose them to the sun so that it would increase the risk of lice breeding that caused scabies on the towels, then there were still towels that were borrowed and borrowed between students. In this case, there will not be a risk of transmission if lending and borrowing towels is carried out by students who do not suffer from scabies, but it will be a problem if those who borrow and borrow between healthy students and students who suffer from scabies. This is a way for the transmission of scabies to correctional students in special coaching institutions for class II children in Pekanbaru City.

The same Hasih is also found in Ma'rufi's (2012) study which states that the behavior that supports the occurrence of scabies is often changing towels with roommates.

According to Yudhastuti (2011), the habit of exchanging towels is a potential for scabies because towels from a person with scabies or personal items that have been contaminated by the sufferer can be a potential transfer or transmission of mites to the skin of a person who does not suffer from scabies. Meanwhile, according to Mansyur (2007) transmission through indirect contact such as through toiletries, in this case can be towels and bar soap, bedding also plays an important role in the transmission of scabies.

The results of the analysis of the relationship between sanitation and the incidence of scabies using the chi-square test obtained a value of $p=0.042(p<0.05)$ so that it can be seen that there is a relationship between sanitation and the incidence of scabies in the Class II Special Development Institute for Children in Pekanbaru City. Based on the results of research on the environmental sanitation variable, it is known that there are 26 students who have good environmental sanitation $(21.7 \%)$ while 94 children who have poor environmental sanitation $(78.3 \%)$.

Sanitation is a health effort by maintaining and protecting the cleanliness of the environment from the subject, for example by providing clean water for the toilet (bathing, washing, caskus), ventilation which must meet the requirements so that air change can run properly so that there is no disturbance to breathing. Density of occupants must be adjusted to the health requirements for the minimum occupant density of $10 \mathrm{~m} 2 /$ person and the prison 
floor must use a waterproof material so that it is not easy for microorganisms to breed (Suyono, 2005).

Environmental sanitation in the special guidance institute for Class II children in Pekanbaru City is still not good enough. It can be seen from the availability of clean water that is not evenly distributed with the number of students, the number of occupants of the room that is not proportional to the area of the residential room, some ventilation that does not meet the requirements, the difficulty of sunlight entering the residential room because it is covered by a barrier, the state of the small room is requires students to sleep side by side, air is not free to go in and out. The sanitation condition of the children's prisons puts them at high risk for the spread of scabies among students.

The results of this study are in line with Erna's (2013) study which states that there is a significant relationship between environmental sanitation which includes occupancy density, availability of clean water, ventilation, and floor conditions with the incidence of scabies in class IIA Jambi prisons. Scabies is closely related to poor hygiene and environment, therefore preventing the spread of scabies can be done by maintaining personal and environmental hygiene (Agoes, 2009).

\section{Conclusion}

Based on this research, it was found that there was no relationship between the variables of age, length of stay, and knowledge with the incidence of scabies in students in special guidance institutions for class II children in Pekanbaru City. Whereas in the variables of cleanliness of clothes, clean towels, and environmental sanitation, there was a significant relationship with the incidence of scabies in students in the special training institute for class II children in Pekanbaru City.

\section{References}

Agoes, R, (2009). Scabies ; Konsep pencegahan dan pengobatan pada komunitas di indonesia, Majalah Kedokteran Bandung. Diakses dari http://lubma2research.blogspot.co $\mathrm{m} / 2011 / 04$

Ariningtyas, D. N. (2019). Analisis karakteristik dan higiene individu dengan kejadian skabies. Jurnal Keperawatan Muhammadiyah

Azizah, Novi N. (2013). Hubungan antara kebersihan diri dan lama tinggal terhadap penularan penyakit skabies di pon-pes al hamdulillah rembang.skripsi.surakarta : Universitas Muhamadiyah Surakarta

Dinas Kesehatan Provinsi Riau. 2016. Profil Kesehatan Provinsi Riau Tahun 2015. Riau.

Djuanda A. (2007). Skabies. Ilmu penyakit kulit dan kelamin. (Edisi ke-5)

Erna, E., \& Marta, M. (2013). Hubungan sanitasi lingkungan dan personal hygiene dengan kejadian penyakit scabies pada warga binaan pemasyarakatan di lembaga pemasyarakatan klas IIA jambi tahun 2013. Scientia Journal, 2(2), 70-78.

Farihah, Ummu. (2016). Analisis karakteristik santri, higiene perorangan dan sanitasi lingkungan dalam pengendalian skabies (studi di pondok pesantren qomaruddin kabupaten gresik). (Skripsi.Surabaya). Universitas Airlangga

Husda, H and Zubaida. (2018). Role Optimization of Indigenous Institutions for Case of Violence Against Women and Children (Analysis Study in Aceh and Padang Provinces). Budapest International Research and Critics Institute-Journal (BIRCI-Journal). P. 170180 
IACS. 2014. Skabies. http;//www.controlscabies.org/about-scabies/. Tanggal 20 Agustus 2019.

Julia, Rochis dan Sri T. B. U. (2013).Hubungan faktor lingkungan dan perilaku terhadap kejadian skabies di pondok pesantren al-furqon kecamatan sidayu kabu $p$ paten gresik provinsi jawa timur tahun 2013 (Skripsi). Universitas Indonesia, Jakarta.

Kemenkes RI. (2016). Profil Kesehatan Indonesia 2015. Keputusan Menteri Kesehatan Republik Indonesia. Jakarta

Ma'rufi I, Erdi I. dan Eri W. (2012). Hubungan perilaku se $\neg$ hat santri dengan kejadian scabies di pondok pe $\neg$ santren kabupaten lamongan. .Jurnal IKESMA, 8(2): pp.119-129. Dfsdh

Mansyur. M. (2007). Pendekatan kedokteran keluarga pada penatalaksanaan skabies anak usia pra-sekolah. Majalah Kedokteran Indonesia . Vol. 57, No. 2, Februari 2007. Hal : 63-67

Noor, Nur Nasry. (2008). Epidemiologi. Jakarta: Rineka Cipta

Notoatmodjo, S.. (2007). Promosi Kesehatan dan Ilmu Perilaku. Jakarta : Rineka Cipta.

Notoatmodjo, S. (2012). Metodologi penelitian kesehatan. Jakarta : Rineka Cipta.

Pawening, A. (2009). Perbedaan angka kejadian skabies antar kelompok santri berdasar lama belajar di pesanten. Universitas Negeri Semarang

Ridwan, A. R., Sahrudin, S., \& Ibrahim, K. (2017). Hubungan pengetahuan, personal hygiene, dan kepadatan hunian dengan gejala penyakit skabies pada santri di pondok pesantren darul muklisin.. Jurnal Ilmiah Mahasiswa Kesehatan Masyarakat, Kendari.

Rohmawati RN. (2010). Hubungan antara faktor pengetahuan dan perilaku dengan kejadian skabies di pondok pesantren al-muayyad surakarta. Fakultas Kedokteran Universitas Muhammadiyah, Surakarta.

Shinta, H., et al. (2020). Potential Stunting in Riverside Peoples (Study on Pahandut Urban Village, Palangka Raya City). Budapest International Research and Critics InstituteJournal (BIRCI-Journal). P. 1618-1625

Soedarto, M. (2003). Skabies dalam daili sf, makes wib, zubier f, dkk. penyakit menular seksual. (Edisi ke-2). FKUI, Jakarta.

Suyono, B. (2011). Ilmu kesehatan masyarakat dalam konteks kesehatan lingkungan. Penerbit Buku Kedokteran, EGC, Jakarta.

WHO. (2009). Epidemiology and management of common skin disease in children in developing countries. (serial di internet). (http://www.who.int/bulletin/volumes/87/2/07047308/en/edit, diakses 12 Agustus 2019). 